\title{
Pengaruh Sarana dan Prasarana Terhadapa Mutu Pendidikan di Madrasah Bertaraf Internasional Nurul Ummah Pacet Mojokerto
}

\author{
Tri Adi Muslimin ${ }^{1}$, Ari Kartiko ${ }^{2}$ \\ ${ }^{1,2}$ Fakultas Tarbiyah Institut Pesantren Kh. Abdul Chalim Pacet Mojokerto \\ e-mail:mrabdullahxim@gmail.com
}

Submitted: 06-08-2020 Revised : 19-08-2020 Accepted: 03-09-2020

\begin{abstract}
Sarana merupakan segala perlengkapan atau peralatan yang digunakan secara langsung dalam proses pembelajaran. Prasarana merupakan segala perlengkapan atau peralatan yang tidak digunakan secara langsung dalam proses pembelajaran. Mutu pendidikan sesuatu yang dapat memenuhi atau bahkan melebihi harapan pelanggan pendidikan. Hal inilah yang terjadi di MBI Nurul Ummah Pacet Mojokerto yang mana sarana dan prasarana yang ada masih kurang memadai tapi dapat menghasilkan mutu pendidikannya sangat tinggi. Rumusan masalah dalam penelitian ini adalah, 1) Bagaimana pengaruh sarana dan prasarana terhadap mutu pendidikan? 2) Manakah yang berpengaruh dominan dari sarana dan prasarana terhadap mutu pendidikan? Sedangkan tujuan penelitian ini untuk mengetahui sejauh mana pengaruh sarana dan prasarana terhadap mutu pendidikan dan dari sarana dan juga mengetahui mana yang lebih berpengaruh domina dari sarana dan prasaran terhadap mutu pendidikan. Jenis penelitian yang digunakn adalah kuantitatif, serta instrumennya menggunakan kuisioner. Kemudian untuk mengetahui pengaruhnya adalah dengan Uji-t. Hasil dari penelitian ini adalah, 1) Bahwa terdapat pengaruh yang signifikan antara sarana, prasarana terhadap mutu pendidikan, 2) Besarnya pengaruh sarana dan prasarana terhaap mutu pendidikan 36,4\%. Sedangkan pengaruh prasarana terhadap mutu pendidikan $17,0 \%$. Maka diketahui bahwa variabel sarana yang paling dominan mempengaruhi mutu pendidikan, 3) Hasil uji koefisien determinasi (R2) diketahui nilai R Square sebesar 0,147, hal ini mengandung arti bahwa pengaruh variabel X1 dan X2 secara simultan terhadap variabel Y adalah sebesar 14,7\%.
\end{abstract}

Keywords: Sarana, Prasarana, Mutu Pendidikan, Madrasah

doi) https:

How to Cite Muslimin, T. A., \& Kartiko, A. (2020). Pengaruh Sarana dan Prasarana Terhadapa Mutu Pendidikan di Madrasah Bertaraf Internasional Nurul Ummah Pacet Mojokerto. Munaddhomah: Jurnal Manajemen Pendidikan Islam, 1(2), 75-87.

\section{PENDAHULUAN}

Penelitian yang layak harus mengedepankan alasan tertentu. Alasan meneliti inilah yang dalam bahasa penelitian disebut research gap. Pertama, penelitian ini mendesak karena meneliti tentang sarana dan prasarana sebagai bagian terpenting mengatasi kualitas pendidikan. Penelitian ini juga menarik dengan alasan mengkaji tentang mutu pendidikan. Dan, penelitian ini unik karena meneliti sekolah atau madrasah khususnya di MBI Nurul Ummah yang banyak diketahui sebagai sekolah dengan prestasi meski memiliki keterbatasan.

Pendidikan merupakan salah satu dasar untuk memajukan suatu negara (A. Rusdiana, 2014; Akhiruddin, 2015). Ketika pendidikan itu bermutu maka bermutu jugalah generasi selanjutnya, sementara itu, bermutu atau tidak suatu pendidikan di suatu negara bisa terlihat dari penyelenggaraan pendidikannya (Fajriana \& Aliyah, 2019; Hamdi, 2019; Jerry H, 2011). Semakin 
bermutu pendidikannya, maka akan semakin maju negara tersebut. Pendidikan adalah dasar yang utama bagi suatu negara, apalagi untuk negara yang masih berkembang. Pembangunan itu bisa dilaksanakan oleh orang yang berpendidikan (Abdullah \& Safarina, 2015; Abdurrahman, 2016). Pendidikan yang terarah, terbit dan teratur sangat diperlukan adanya manajemen, tanpa manajemen akan sangat sulit dicapainya tujuan pendidikan yang optimal, efektif, dan efisien. Sebagaimana yang telah kita ketahui bersama bahwa pendidikan itu bermacam-macam, ada pendidikan formal seperti sekolah dan ada juga pendidikan non formal seperti pesantren. Pesantren dulu hanya sebuah lembaga pendidikan non formal, namun sekarang di pesantrenpun ada pendidikan formalnya berupa sekolah (Arifin, 2017; Bashori, 2017; Chotimah, 2014).

Pesantren yang dulunya hanya sebuah lembaga pendidikan non formal yang siswanya atau santrinya hanya menekuni pada bidang keagamaan saja, tetapi santri saat ini juga harus mampu menguasai pendidikan formal maka saat di pesantrenun ada pendidikan formalnya(Asrohah, 2011; Chairi, 2019; Ma`arif, 2017). Salah satu yang bisa meningkatkan mutu suatu pendidikan yaitu adanya sarana dan prasarana yang memadai. Sarana merupakan peralatan atau perlengkapan yang dipakai dalam proses pembelajaran secara langsung, sedangkan prasarana merupakan peralatan atau perlengkapan yang menunjang proses pembelajaran secara tidak langsung (Farid \& Daryanto, 2013, p. 106). MBI (Madrasah Bertaraf Internasional) Nurul Ummah merupakan lembaga pendidikan yang beroprasional dibawah naungan pondok pesantren Amanatul Ummah, dengan peraturan yang ketat bagi santri atau muridnya, dengan guru yang berkompeten di bidangnya dan pembimbing yang memiliki kompeten sesuai yang dinginkan oleh lembaga(Maarif \& Rofiq, 2018).

Melihat fakta yang terjadi di MBI (Madrasah Bertaraf Internasional) Nurul Ummah penulis melihat ini adalah sebuah masalah tapi positif yaitu sarana dan prasarana yang ada kurang memadai seperti belum adanya kelas yang mencukupi untuk semua siswa seperti ada tiga kelas yang bertempat dalam sebuah masjid tapi dapat menghasilkan mutu pendidikan yang luar biasa yang ditandai dengan adanya lulusan MBI (Madrasah Bertaraf Internasional) Nurul Ummah yang mendapatkan beasiswa di Eropa, Timur Tengah dan Perguruan Tinggi favorit di Indonesia. Mutu pendidikan merupakan sebuah harapan yang dapat memuaskan pelanggan pengguna jasa pendidikan baik itu wali siswa maupun siswa itu sendiri. Maka ketika semua itu memenuhi harapan pelanggan, seperti harapan pelanggan yang menyekolahkan anaknya di MBI (Madrasah Bertaraf Internasional) Nurul Ummah yaitu mendapatkan beasiswa baik di Eropa, Timur Tengah dan Perguruan Tinggi Favorit Indonesia dan jika itu tercapai maka bisa dikatakan sebuah pendidikan itu bermutu karena sudah sesuai harapan pelanggan pengguna jasa pendidikan.

Sebagaimana yang telah kita ketahui bersama jika sarana dan prasarana kurang memadai bisa menggangu proses pembelajaran sehingga mutu atau kualitas pendidikaan rendah, namun yang terjadi di MBI (Madrasah Bertaraf Internasional) Nurul Ummah cukup unik yaitu sarana dan prasarana kurang memadai tapi dapat mengahasilkan mutu pendidikan yang baik. Apakah ini juga memberi isyarat kepada kita bahwa mutu pendidikan bukan hanya bisa didapat dengan sarana dan prasarana yang memadai saja, yang kurang memadaipun bisa asalkan ada niatan dan usaha yang kuat untuk mencapai mutu dengan menggunakan faktor yang lain seperti input yang memiliki kecerdasan yang tinggi atau budaya belajar yang baik di sebuah lembaga. Maka kami meneliti apakah sarana dan prasarana mempengaruhi mutu pendidikan di MBI (Madrasah Bertaraf Internasional) Nurul Ummah atau tidak, atau sarana yang lebih berpengaruh atau prasarana yang lebih berpengaruh atau bahkan tidak ada pengaruhnya sama sekali ke mutu pendidikan. Sesuai hal yang telah dipaparkan sebelumnya, maka peneliti akan melaksanakan penelitian yang tentunya berbeda dengan penelitian sebelumnya yang penulis cantumkan dalam penelitian terdahulu relevan yaitu yang menekankan pada mutu pendidikan dengan judul "Pengaruh Sarana dan Prasarana Terhadap Mutu Pendidikan di MBI (Madrasah Bertaraf Internasional) Nurul Ummah".

Sesuai latar belakang yang telah dikemukakan diatas, bisa diketahui permasalahan sebagai berikut yaitu berdasarkan hasil observasi di sekolah MBI (Madrasah Bertaraf Internasional) Nurul Ummah didapatkan keterangan bahwa sarana dan prasarana masih perlu ditingkatkan, ini ditandai 
dengan adanya sarana dan prasarana yang belum memadai. Dan dalam rangka meningkatkan sarana dan prasarana perlu diberikannya pengarahan yang jelas kepada pengurus sekolah baik kepada kepala sekolah maupun pengurus lainnya. Salah satu dari faktor-faktor yang dapat mempengaruhi mutu pendidikan yaitu sarana dan prasarana di lingkungan MBI (Madrasah Bertaraf Internasional) Nurul Ummah. Permasalahan bisa dirumuskan sebagai berikut yaitu deskripsikan sarana, prasarana dan mutu pendidikan di MBI (Madrasah Bertaraf Internasional) Nurul Ummah?, bagaimana pengaruh sarana dan prasarana terhadap mutu pendidikan di MBI (Madrasah Bertaraf Internasional) Nurul Ummah? Serta manakah yang berpengaruh dominan dari sarana dan prasarana terhadap mutu pendidikan di MBI (Madrasah Bertaraf Internasional) Nurul Ummah?

Tujuan penelitian ini yaitu mendeskripsikan sarana, prasarana dan mutu pendidikan, menjelaskan dan menganalisa pengaruh variabel sarana dan prasarana terhadap mutu pendidikan di MBI (Madrasah Bertaraf Internasional) Nurul Ummah serta menjelaskan dan menganalisis yang lebih berpengaruh dominan dari variabel sarana dan prasarana terhadap mutu pendidikan di MBI (Madrasah Bertaraf Internasional) Nurul Ummah. Kegunaan penelitian ini yaitu menambah pengalaman serta pengetahuan baru bagi penulis didalam penerapan dan pelaksanaan ilmu pengetahuan, manfaat bagi kepala sekolah sebagai pengambil keputusan agar mengetahui pengaruh sarana dan prasarana terhadap mutu pendidikan, menambah khazanah baru bagi peneliti selanjutnya agar dapat dijadikan rujukan penelitiannya serta hasil penelitian diharapkan bisa mendorong peneliti selanjutnya, khususnya didalam bidang mutu pendidikan di sebuah lembaga pendidikan.

Penelitian terdahulu yang relevan pada penelitian ini yaitu, 1) (Wafi, 2016) melakukan penelitian yang berjudul "Pengaruh Pemanfaatan Sarana dan Prasarana Belajar Terhadap Prestasi Belajar Pendidikan Agama Islam Siswa Kelas X di SMA N 11 Semarang”. Hasil penelitian tersebut bisa ditarik kesimpulan yaitu berpengaruh positif dan signifikan variabel pemanfaatan sarana dan prasarana belajar terhadap prestasi belajar Pendidikan Agam Islam siswa kelas X di SMA N 1 Semarang (Y) sebesar 0,65 atau 65\%. 2) Alif Futikha Ulfa (2015), melakukan penelitian yang berjudul "Pengaruh Sarana dan Prasarana Pendidikan Terhadap Minat Membaca Literatur Ekonomi dan Prestasi Belajar Mata Pelajaran Ekonomi Siswa Kelas XI IPS SMA N 1 Jakenan Pati”. Hasil Penelitian tersebut diantaranya yaitu berpengaruh positif dan signifikan sarana dan prasarana terhadap minat baca pada siswa dan tidak terdapat hubungan sarana dan prasarana terhadapa minat baca siswa. 3) (Ari Fuazi, 2018) Hasil penelitian tersebut dapat ditarik kesimpulan bahwa sarana dan prasarana tidak berpengaruh terhadap prestasi belajar mahasiswa, hunungan sarana dan prasarana masuk alam katagori sangat kecil yaitu 5,29\%. Tidak ada perbedaan prestasi belajar anatara mahsiswa di Pesantren Sulaimaniyah yang sarana dan prasarana pesantrennya kurang memadai. Karena rat-rata mahasiswa di Pesantren Sulaimaniyah dan Nurul Awal samasama mendapatkan nilai sedang di Pesantren Sulaimaniyah 10 orang mahasiswa yang memperoleh IPK 3,00-,50, sedangkan di Pesantren Nurul Awal 11 orang mahasiswa mendapatkan IPK 3,003,50 .

\section{KAJIAN TEORI}

Mutu pendidikan berasal dari dua kata yaitu mutu dan pendidikan. Didalam bahasa Inggris "quality artinya mutu, kualitas(Indonesien \& Pusat Bahasa (Indonesia), 2013)". Dalam kamus Besar Bahasa Indonesia "Mutu adalah (ukuran), baik buruk suatu benda; taraf atau derajat (kepandaian, kecerdasan, dsb)". Mutu adalah "Kualitas memenuhi atau melebihi harapan pelanggan"(Nasution, 2004). Berdasarkan hal tersebut mutu yaitu kualitas yang mampu memenuhi atau melebihi harapan. Pendidikan adalah usaha terencana yang sadar agar dapat menjadikan proses dan suasana belajar yang dapat membuat murid aktif yang bisa mengembangkan potensi dirinya agar dapat mempunyai kecerdasan, kepribadian, akhlak mulia, pengendalian diri, kekuatan spritual keagamaan, dan ketrampilan yang berguna bagi dirinya, masyarakatnya, bangsanya dan 
negaranya. Mutu pendidikan adalah pendidikan yang seluruh komponen pendukungnya dapat memuaskan peserta didik, guru, pimpinan dan masyarakat (Nata, 2003).

Secara terminologi, mutu mempunyai penjelasan bermacam-macam, mempunyai banyak tafsir dan perbedaan. Ini dikarenan tidak adanya ukuran yang pasti tentang mutu itu sendiri. Maka itu membuat sulit untuk menemukan sebuah jawaban yang sama, tentang hal yang bermutu atau tidak (Sulistyorini, 2012). Mutu merupakan sesuatu yang kompleks yang telah menjadi salah satu daya tariknya dalam semua teori manajemen. Lyod Dobbins dan Crawfor Mason telah mewancarai banyak penulis tentang mutu, dan mereka menyimpulkan bahwa "tidak ada 2 orang yang berbicara dengan kami dapat menyetujui dengan tepat bagaimana mendefinisikan mutu". Mereka mengutip John Steward, seorang Konsultan di Mc.Kinsey "Tidak ada pengertian mengenai mutu. Mutu adalah perasaan yang merasakan bahwa hal itu lebih baik dari pada yang lain. Perasaan itu berubah sepanjang waktu, merubah dari generasi ke generasi, dan bermacam-macam dengan aktivitas manusia (Stoner et al., 1996, p. 210).

Menurut Pleffer dan Coote sebagaimana dikutip Aan Komariah, secara esensial mutu memberikan arti kepada sesuatu ukuran penilaian atau penghargaan yang diberikan atau dikenakan pada barang (products) atau kinerjanya (Aan \& Cepi, 2005). Menurut B. Suryobroto dalam (Pidarta, 2011), konsep "mutu" mempunyai pengertian derajat (tingkat) unggulnya suatu produk (hasil kerja/upaya) baik berupa barang maupun jasa, baik yang tangible maupun intangible. Sebagaimana dikutip Amin Widjaya, Gregory B. Hutchins menyatakan bahwa mutu adalah "kesesuaian/kecocokan dengan spesifikasi dan standar yang berlaku; cocok/pas untuk digunakan; dapat memuaskan keinginan, kebutuhan dan pengharapan pelanggan dengan harga yang kompetitif (Tunggal, 1992). (Aan \& Cepi, 2005) menyatakan bahwa mutu merupakan suatu ukuran penilaian atau penghargaan yang diberika kepada barang dan atau jasa tertentu berdasarkan pertimbangan obyektif atas bobot atau kinerjanya. Menurut (Crosby, 1995) mutu adalah sesuai yang disyaratkan atau distandarkan, yaitu sesuai dengan standar mutu yang telah ditentukan, baik inputnya, prosesnya maupun outputnya(Mulyadi, 2010). Menurut Feigenbaum, sebagaimana dikutip (Syafaruddin, 2002), mutu adalah kepuasan pelanggan sepenuhnya. Suatu produk dianggap bermutu apabila dapat memberikan kepuasan sepenuhnya pada konsumen, yaitu sesuai dengan harapan konsumennya atas roduk atau jasa yang diahsilkan. Pendiidkan yang bermutu adalah pendidikan yang dapat menghasilakan keluaran, baik pelayanan dan lulusan yang sesuai kebutuhan atau harapan pelanggannya(Sulistyorini, 2012).

Mutu pendidikan sering diindakasikan dengan kondisi yang baik, memenuhi syarat, dan segala komponen yang harus terdapat dalam pendidikan, komponen-komponen tersebut adalah masukan, proses, keluaran dan tenaga kependidikan, sarana dan prasaran dan biaya. Sagala menyatakan, bahwa lembaga pendidikan dapat dikatan bermutu, apabila prestasi sekolah khususnya prestasi peserta didik, menunjukkan capaian yang tinggi dalam prestasi akademik, yaitu raport dan nilai kelulusan memenuhi standar yang ditentukan, memiliki nilai-nilai kejujuran, ketaqwaan, kesopanan, dan mampu mengapresiasi nilai-nilai budaya dan memiliki tanggungjawab yang tinggi dan kemampuan yang diwujudkan dalam bentuk ketrampilan, sesuai dengan standar ilmu yang diterima disekolah (Sagala, 2018) (Sagala, 2016). Mansur merumuskan bahwa kualitas pendidikan dapat dilihat dari segi proses dan produknya. Sutau pendidikan disebut bermutu dilihat dari proses, juga sangat dipengaruhi oleh kualitas masukannya atau disebut input. Proses belajar mengajar dikatakan efektif, apabila selma proses belajar mengajar berlangsung, peserta didik mengalami proses pembelajaran yang bermakna. Dalam hal ini proses pendidikan tidak hanya berjalan engan lancar dan baik melaiankan proses pendidikan khususnya proses pembelajaran dapat memposisikan peserta didik sebagai subyek mendapatkan perlakukan secara humanistik, sehingga peserta didik memiliki rasa kebebasan yang cukup untuk mengekspresikan segala potensinya. Kedua, pendidikan disebut berkualitas dari segi produk, jika peserta didik menunjukakan ciri-ciri diantaranya penguasaan yang tinggi terhadap tugas-tugas belajar, hasil 
pendidikannya sesuai dengan kebutuhan hidupnya, dan hasil penddikannya sesuai atau relevan dengan tuntunan lingkungan, khususnya dunia kerja.

\section{METODE PENELITIAN}

Adapun jenis penelitian ini adalah kuantitatif. Penelitian kuantitatif yaitu penelitian yang dilakukan dengan mengumpulkan data yang berupa angka yang kemudian diolah dan dianalisis untuk mendapatkan informasi (Noor, 2011). Penelitian ini berlokasi pada MBI Nurul Ummah di Kembang Belor, Pacet, Mojokerto, Jawa Timur. Penelitian ini dilaksanakan oleh peneliti memakai satu jenis data untuk memecahkan masalah, yaitu data utama merupakan data yang didapatkan dari para responden yang dipilih di tempat penelitian. Data utama didapatkan dari penyebaran angket.

Instrumen penelitian ini memakai Skala Likert yaitu sebuah bentuk skala yang meberikan tanda jawaban para responden setuju atau tidak setuju atas pertanyaan atau pernyataan tentang suatu obyek. Skala Likert mengukur kisaran jawaban 1-5. Katagori jawabannya yaitu sangat setuju dengan nilai 5 , setuju dengan nilai 4 , netral dengan nilai 3, tidak setuju dengan nilai 2 dan sangat tidak setuju dengan nilai 1 . Penelitian ini memakai kuesioner, untuk mengumpulkan data digunakan metode penyebaran kuesioner untuk di isi oleh responden. Mengenai obyek penelitian diperoleh dari pengumpulan data dari dokumen-dokumen yang ada di MBI (Madrasah Bertaraf Internasional) Nurul Ummah.

Populasi Penelitian yaitu semua objek penelitian yang baik yang berupa orang, hewan, tumbuhan, udara, nilai, sikap hidup dan lain lainnya(Burhan Bungin, 2006). Mengenai populasi penelitian ini adalah seluruh guru MBI (Madrasah Bertaraf Internasional) Nurul Ummah Mojokerto. Jumlah populasi adalah 145 orang guru. Sampel Penelitian yaitu bagian dari jumlah yang ada di suatu populasi. Apabila populasinya besar, dan tidak mungkin meneliti semuanya yang berada di populasi itu (Sugiyono, 2014), maka bisa mengambil sampel yang berada di populasi itu. Apabila subjeknya kurang dari 100 maka diambil semuanya, dan apabila lebih dari 100 maka dapat diambil 10\% sampai $15 \%$ atau 20\% sampai 25\% atau lebih (Suharsimi, 2010). Berdasarkan hal demikian kami mengambil sampel penelitian ini sejumlah 50 dari jumlah populasi 145 guru. Adapun teknik pengambilan sampel di penelitian ini yaitu memakai teknik aksidental sampel. Teknik pengambilan aksidental sampel adalah teknik yang didasarkan pada kebetulan, yakni siapapun yang ditemukan oleh peneliti dengan bertemu maka bisa dijadikan sampel (Masnur, 2007).

Teknik analisis data pada penelitian ini menggunakan analisis Regresi Linear Berganda (Multiple Linear Regression), rumusnya adalah sebagai berikut :

$$
\mathrm{Y}=\mathrm{b} \_0+\mathrm{b} \_1 \mathrm{X} \_1+\mathrm{b} \_2 \mathrm{X} \_2+\mathrm{b} \_3+\mathrm{e}
$$

Dimana :

$$
\mathrm{X} 1=\text { Sarana }
$$

$\mathrm{X} 2=$ Prasarana

$\mathrm{Y}=$ Mutu Pendidikan penelitian

e $=$ (error) atau segala faktor yang berada luar yang diteliti, tapi memiliki hasilnya dalam

Jika memiliki keterkaitan yang searah diantara variabel $\mathrm{x}$ dan variabel y maka koefisien regresi $\beta$ akan memiliki nilai yang positif $(+)$. Kenaikan yang dialami oleh variabel $\mathrm{x}$ akan memberikan sumbangsih pada kenaikan variabel $\mathrm{y}$ dan juga penuruna pada variabel $\mathrm{x}$ akan memberikan sumbangsih pada penurunan variabel y. Uji validitas kuisioner merupakan satu cara untuk mendapatkan data penelitian kuantitatif. Didalam menyusun kuisioner terlebih dahulu dilakukan uji validitas dan relebialitas(Sugiyono, 1999). Instrumen dinyatakan valid ketika alat ukur 
yang dipakai untuk mengambil data itu valid. Makna valid dalam instrumen berarti bisa dipakai untuk mengukur yang akan diukur dan intrumen yang reliabel memiliki arti jika digunakan berkali kali dalam mengukur maka memiliki hasil data yang sama. Diperlukan korelasi antara item untuk mendapatkan nilai vaiditas. Ketika item itu memenuhi syarat, maka item itu akan diteliti secara lebih lanjut. Syaratnya yang harus mempunyai kriteria seperti ini yaitu jika $r \geq 0,3$ maka valid dan jika $\mathrm{r} \leq 0,3$ tidak valid(Hartono, 2011).

Rumus uji validitas product moment:

$\left.\left.\sum\right)\right)$

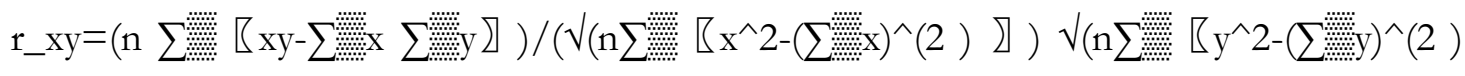

r_xy : koefisien korelasi antara variabel $\mathrm{X}$ dan variabel $\mathrm{Y}$

$\mathrm{x} \_\mathrm{i}$ : nilai data ke-i untuk kelompok variabel $\mathrm{X}$

y_i : nilai data ke-i untuk kelompok variabel Y

$\mathrm{n}$ : banyak data

Uji reliebilitas kuisioner dinyatakan reliabel ketika jawaban yang diberikan memiliki hasil yang sama secara terus menerus. Keterkaitannya itu dijelaskan dengan koefisien $r$, koefisien $r$ berkisar dari 0 sampai dengan 1 dan nilai $>0,6$ artinya butir variabel atau pertanyaan itu adalah reliabel atau bisa dipercaya. Ini artinya data yang dipakai telah pantas dipakai di analisis selanjutnya(Sekaran \& Bougie, 2016).

Rumus uji reliabilitas cronbanch alpha:

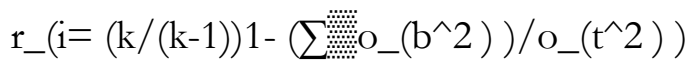

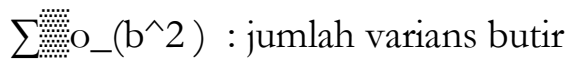

o_ $\left(\mathrm{t}^{\wedge} 2\right)$ : varians total

Uji normalitas memiliki maksud menjelaskan variabel penggangu dalam model regresi memiliki distribusi normal. Caranya yang dipakai menjelaskan variabel penggangu berdisrtribusi normal atau tidak yaitu memakai cara analisis uji statistik atau grafik. Menjadi dasar untuk mengetahui variabel penggangu mempunyai distribusi normal atau tidak maka uji statistik berikutnya bisa disebut valid. Pembuktian datanya itu mempunyai distribusi normal atau tidak bisa diketahui dibentuk distribusi datanya, yaitu pada histogram maupun normal probability plot. Uji multikolineritas dipakai menjelaskan keterkaitan kuat yang terjadi di antara variabel bebas. Cara mengujinya yaitu dengan melihat, apa nilai korelasi antara nilai variabel bebas itu mendekati 1 atau nilai korelasi parsial mendekati 0 , ketika lebih dari 0,8 maka mengisaratkan terjadi mltikolinearitas. Variabel yang baik seharusnya tidak terjadi antara variabel bebas. Gejala multikolinieritas bisa diketahui pada nilai tolerance dan nilai varian inflation factor (VIF). Bila nilai VIF lebih kecil dari 10 dan nilai toleransinya diatas 0,1 atau $10 \%$ maka bisa diketahui bahwa model regresi tersebut tidak terjadi multikolineritas.

Uji heteroskedastisitas dilakukan dengan tujuan dilakukan untuk mengetahui error varian (ei) konstan di seluruh kasus dan variabel bebas (independent variabel). Menjelaskan terjadinya heterokedastisitas atau tidak bisa dipakai metode grafik scatterplot yang didapatkan dari output program SPSS, jika di gambar memperlihatkan titik-titik menyebarnya secara acak serta tersebarnya baik diatas maupun dibawah angka 0 pada sumbu $\mathrm{Y}$, maka bisa diketahui tidak terjadi heteroskedastisitas. Pengujian ini digunakan untuk menguji apa sarana dan prasarana masingmasing memiliki pengaruh terhadap mutu pendidikan. Pengujian ini dibagi menjadi dua bagian berikut yaitu Uji t digunakan untuk menjelaskan pengaruh dari masing-masing variabel bebas dan variabel terikat. Pengambilan keputusan didasarkan nilai probabilitas (nilai signifikansi) yaitu jika signifikansi $<0,05$ maka terdapat pengaruh variabel $\mathrm{X}$ terhadap variabel $\mathrm{Y}$ dan jika signifikansi $>$ 
0,05 maka tidak terdapat pengaruh variabel $\mathrm{X}$ terhadap variabel $\mathrm{Y}$ atau pengambilan keputusan didasarkan nilai probabilitas (nilai $\mathrm{t}$ tabel) yaitu jika $\mathrm{t}$ penelitan $>\mathrm{t}$ tabel maka terdapat pengaruh variabel $\mathrm{X}$ terhadap variabel $\mathrm{Y}$ dan jika t penelitian $<\mathrm{t}$ tabel maka tidak terdapat pengaruh variabel $\mathrm{X}$ terhadap variabel $\mathrm{Y}$ atau taraf signifikansi pengaruh variabel bebas terhadap variabel terikat yaitu jika kuat maka 67-100, jika sedang maka 36-66, jika lemah maka 35 kebawah. Rumus t tabel yaitu T tabel $=\mathrm{t}(\mathrm{a} / 2 ; \mathrm{n}-\mathrm{k}-1)$. Keterangannya yaitu $\mathrm{a}=$ kepercayaan $0,05, \mathrm{n}=$ sampel dan $\mathrm{k}=$ jumlah variabel $\mathrm{X}$. Uji $\mathrm{R}^{\wedge} 2$ atau uji koefisien determinasi memberikan penjelasan total persen pada variabel terikat yang dijabarkan oleh variabel bebas. Ukurannya yaitu semakin tinggi nilai $\mathrm{R}^{\wedge} 2$ maka semakin baik garis regresinya. Hasil keputusan $\mathrm{Uji}^{\wedge} \wedge 2$ bisa diketahui dengan dasar jika nilai $\mathrm{R}^{\wedge} 2$ suatu regresi mendekati 1 , maka semakin baik dan jika nilai $\mathrm{R}^{\wedge} 2$ suatu regresi menjauhi 1 , maka variable bebas tidak bisa menjelaskan variabale terikat. Rumus Koefisien Determinasi yaitu $\mathrm{KD}=\mathrm{R}^{\wedge} 2 \times 100 \%$. Uji $\mathrm{F}$ bertujuan keseluruhan variable bebas memiliki pengaruh yang signifikan atau tidak pada variabel terikat. Pengambilan keputusan didasarkan nilai probabilitas (nilai signifikansi) yaitu jika signifikansi $<0,05$ maka ada pengaruh variabel $\mathrm{X}$ terhadap variabel $\mathrm{Y}$ dan jika signifikansi $>0,05$, maka tidak ada pengaruh variabel $\mathrm{X}$ terhadap variabel $\mathrm{Y}$. Pengambilan keputusan didasarkan nilai probabilitas (nilai $\mathrm{F}$ tabel) yaitu jika F-hitung $>$ F-tabel, maka ada pengaruh variabel $\mathrm{X}$ terhadap variabel $\mathrm{Y}$ dan jika F-hitung $<$ F-tabel, maka tidak ada pengaruh variabel $\mathrm{X}$ terhadap variabel $\mathrm{Y}$. Rumus $\mathrm{F}$ tabel yaitu $\mathrm{F}$ tabel $=\mathrm{F}(\mathrm{k} ; \mathrm{n}-\mathrm{k})$. Keterangannya yaitu a $=$ kepercayaan $0,05, \mathrm{n}=$ sampel dan $\mathrm{k}=$ jumlah variabel $\mathrm{X}$

\section{HASIL DAN PEMBAHASAN}

Gambaran umum dan lokasi penelitian yaitu MBI (Madrasah Bertaraf Internasional) Nurul Ummah merupakan salah satu dari Yayasan Pondok Pesantren Amanatul Ummah Surabaya yang berada di kaki Gunung Welirang, tepatnya Kembangbelor, Pacet, Mojokerto, Jawa Timur. Dibangun pada tanggal 25 Mei 2006, MBI Nurul Ummah adalah sekolah menengah atas Islam berbasis pesantren (Islamic boarding school) yang bukan saja melaksanakan pendidikan formal kurikulum nasional, tapi melaksanakan pendidikan diniyah yang disesuaikan kurikulum Madrasah Aliyah al Azhar Mesir (mu'adalah bi al Az̧bar). Berarah kepada pengembangan segala aspek kecerdasan baik kognitif, afektif, psikomotorik, spiritual dan keterampilan (life skill) murid, MBI Nurul Ummah berusaha semaksimalnya dalam melaksanakan kegiatan baik yang berupa intra ataupun yang berupa ekstra kurikuler yang menampung bakat, potensi dan minat murid-murid dengan memberikan arahan secara intensif. Sejak jam 3 pagi sampai jam 6 pagi, murid-murid disiapkan agar melaksanakan jamaah sholat Tahajjud, sholat Subuh dan istighotsah serta pengajian kitab bersama pengasuh pesantren sebagai ciri khas pesantren yang berguna sebagai mengasah kecerdasan spiritual murid-murid. Proses belajar mengajar yang digabung dari kurikulum Nasional dan Internasional berlangsung mulai jam 7.00 WIB sampai jam 15.30 WIB dalam bimbingannya guru-guru berkompeten dalam bidang keilmuannya sehingga pada akhirnya menjadikan anak didik bukan saja mempelajari materi kurikulum, tapi juga mempelajari gabungan dengan kehidupan yang nyata yaitu keseharian dalam hidup dan materi pelejaran yang berolipimpiade. Setelah istirahat siang dan sholat Ashar berjamaah sampai jam 20.10 malam, murid-murid melaksanakan proses belajar mengajar diniyah muadalah di dalam naungan kurikulum Madrasah Aliyah al-Azhar Mesir yang bimbingan ustadz-ustadzah sehingga menjadikan murid-murid untuk seimbang dalam keilmuan umum dan agama.

Proses belajar mengajar di MBI Nurul Ummah dipegang oleh guru-guru berkompeten dalam bidangnya masing-masing, baik kelas kurikulum formal di pagi hari maupun kelas muadalah di malam hari. Guru-guru kurikulum formal merupakan lulusan S1, S2 dan S3 dari berbagai perguruan terkemuka di Indonesia maupun luar negeri. Begitu juga ustadz-ustadzah kelas muadalah yang mengajarkan materi kurikulum Madrasah al Azhar termasuk Ilmu al-Quran, Ilmu Hadits, Nahwu, Shorf, Balaghoh, Mantiq, Fiqh, Ushul Fiqh, dan sebagainya. Untuk mengembangkan profesionalisme guru maka sering dilaksanakannya workshop, seminar keguruan 
secara berkala dan bantuan biaya pendidikan studi lanjut bagi guru-guru ke jenjang S2 dan S3. Ini dilaksanakan agar guru-guru yang tugasnya berada pada garda terdepan pendidikan di MBI Nurul Ummah bisa mengatur proses belajar mengajar yang kreatif dan inovatif.

Tabel dibawah ini menunjukkan bahwa sejak berdirinya yaitu di tahun ajaran 2006-2007 hingga tahun ajaran 2018-2019, jumlah murid terus mengalami kenaikan. Kenaikan jumlah murid pada setiap tahunnya memberikan bukti masyarakat sangat berminat terhadap MBI Amanatul Ummah dan pengakuan terhadap prestasi-prestasi telah diraih. Mulai dari lulusan angkatan pertamanya di tahun 2009, MBI Nurul Ummah telah berhasil mengeluarkan lulusan atau output dengan rata-rata nilai sesuai bahkan melebihi harapan. juga, setiap angkatan bisa masuk ke kampus-kampus favorit baik dalam ataupun luar negeri dengan beasiswa dan reguler. Keluaran dari proes belajar mengajar ketat dan intensif di MBI Nurul Ummah merupakan prestasi para lulusan yang bisa masuk universitas-universitas favorit baik dalam ataupun luar negeri. Juga puluhan prestasi yang sangat membanggakan pernah diraih oleh murid-murid dalam berbagai macam olimpiade dan kopetisi serta lomba ekstra kurikuler tingkat regional atupun nasional.

Deskripsi data ini akan menjelaskan jenis kelamin, latar belakang pendidikan dan masa kerja responden. Jenis kelamin terbagi atas 2 responden yaitu pria dan wanita. Setelah kuisioner disebarkan kepada 50 orang responden maka dilakukanlah identifikasi tehadap responden yang menjadi sampel sebagai berikut. Berdasarkan jenis kelamin maka responden didomonasi oleh pria 27 orang atau 54\% sedangkan wanita 23 orang atau 46\%. Latar belakang pendidikannya responden maka responden terbanyak mempunyai pendidikan S1 sebanyak 36 orang atau $72 \%$ dan yang lebih sedikit yaitu S2 sebanyak 14 orang atau 28\%. Masa kerja responden didapati masa kerja kurang dari 3 tahun adalah sebanyak 16 orang (32\%), dan masa kerja lebih dari 10 tahun adalah 7 orang (14\%).

Uji instrumen ini dilakukan oleh uji validitas dan reliabilitas kuesioner. Kuesioner sudah dibagikan kepada 50 responden. Untuk uji validitas, apabila kurang dari standar 0,3 maka hasilnya tidak valid. Sedangkan untuk uji reliabilitas, apabila didapat nilai Cronbach Alpha $<0,60=$ jelek, Cronbach Alpha 0,60-0,70 = diterima dan Cronbach Alpha $>0,80=$ baik. Berdasarkan uji validitas dan reliabiltas didapatkan hasil sebagai berikut :

Tabel Uji Validitas Variabel Sarana (X1)

\begin{tabular}{|c|c|c|c|}
\hline $\begin{array}{c}\text { No } \\
\text { Pertanyaan }\end{array}$ & $\begin{array}{c}\text { Standar Nilai } \\
\text { Uji Validitas }\end{array}$ & $\begin{array}{c}\text { Hasil Uji } \\
\text { Validitas }\end{array}$ & $\begin{array}{c}\text { Keterangan } \\
\text { Validitas }\end{array}$ \\
\hline 1 & 0,3 & 0,547 & Valid \\
\hline 2 & 0,3 & 0,633 & Valid \\
\hline 3 & 0,3 & 0,619 & Valid \\
\hline 4 & 0,3 & 0,685 & Valid \\
\hline 5 & 0,3 & 0,712 & Valid \\
\hline 6 & 0,3 & 0,387 & Valid \\
\hline 7 & 0,3 & 0,606 & Valid \\
\hline Hasil & 0,3 & & \\
\hline
\end{tabular}

Berdasarkan tabel dapat diketahui bahwa semua butir pertanyaan 1-7 didalam kuesioner untuk variabel sarana dinyatakan valid, dikarenakan semua nilai lebih besar daripada standar uji validitas $(0,3)$.

Tabel Uji Validitas Variabel Prasarana (X2) 


\begin{tabular}{|c|c|c|c|}
\hline No Pertanyaan & $\begin{array}{c}\text { Standar Nilai Uji } \\
\text { Validitas }\end{array}$ & $\begin{array}{c}\text { Hasil Uji } \\
\text { Validitas }\end{array}$ & $\begin{array}{c}\text { Keterangan } \\
\text { Validitas }\end{array}$ \\
\hline 1 & 0,3 & 0,460 & Valid \\
\hline 2 & 0,3 & 0,558 & Valid \\
\hline 3 & 0,3 & 0,486 & Valid \\
\hline 4 & 0,3 & 0,524 & Valid \\
\hline 5 & 0,3 & 0,777 & Valid \\
\hline 6 & 0,3 & 0,738 & Valid \\
\hline 7 & 0,3 & 0,686 & Valid \\
\hline 8 & 0,3 & 0,581 & Valid \\
\hline 9 & 0,3 & 0,772 & Valid \\
\hline 10 & 0,3 & 0,762 & Valid \\
\hline 11 & 0,3 & 0,439 & Valid \\
\hline 12 & 0,3 & 0,653 & Valid \\
\hline 13 & 0,3 & 0,704 & Valid \\
\hline 14 & 0,3 & 0,527 & Valid \\
\hline 15 & 0,3 & 0,436 & Valid \\
\hline 16 & 0,3 & 0,596 & Valid \\
\hline 17 & 0,3 & 0,665 & Valid \\
\hline 18 & 0,3 & 0,736 & Valid \\
\hline 19 & 0,3 & 0,698 & Valid \\
\hline 20 & 0,3 & 0,539 & Valid \\
\hline 21 & 0,3 & 1 & Valid \\
\hline Hasil & 0,3 & & \\
\hline
\end{tabular}

Berdasarkan tabel bisa diketahui bahwa semua butir pertanyaan 1-21 dalam kuesioner variabel prasarana dinyatakan valid dikarenakan semua nilai lebih besar daripada nilai standar uji validitas $(0,3)$

Tabel Uji Validitas Variabel Mutu Pendidikan (Y)

\begin{tabular}{|c|c|c|c|}
\hline No Pertanyaan & $\begin{array}{c}\text { Standar Nilai Uji } \\
\text { Validitas }\end{array}$ & $\begin{array}{c}\text { Hasil Uji } \\
\text { Validitas }\end{array}$ & $\begin{array}{c}\text { Keterangan } \\
\text { Validitas }\end{array}$ \\
\hline 1 & 0,3 & 0,689 & Valid \\
\hline 2 & 0,3 & 0,776 & Valid \\
\hline 3 & 0,3 & 0,851 & Valid \\
\hline 4 & 0,3 & 0,653 & Valid \\
\hline 5 & 0,3 & 0,797 & Valid \\
\hline 6 & 0,3 & 0,679 & Valid \\
\hline 7 & 0,3 & 0,742 & Valid \\
\hline Hasil & 0,3 & & \\
\hline
\end{tabular}

Berdasarkan tabel bisa diketahui bahwa semua butir pertanyaan 1-7 dalam kuesioner variabel Mutu Pendidikan dinyatakan valid dikarenakan semua nilai lebih besar daripada nilai standar uji validitas $(0,3)$.

Uji reliabilitas dalm penelitian ini dilakukan terhadap butir pernyataan yang telah teruji validitasnya, teknik pengukuran realibilitas ini dilakukan dengan mengkorelasikan nilai $A \not p h a$ Cronbach, jika nilai alpha setara atau lebih dari 0.60 pada tingkat taraf $\alpha=0.05$ maka butir pertanyaan dari seluruh variabel dianggap signifikan atau reliabel. Berikut ini disajikan hasil uji 
reliabiltas data dengan memakai bantuan program SPSS 18.0 for windows dalam bentuk tabel hasil uji reliabilitas data variabel penelitian, sebagai berikut :

Tabel Hasil Uji Reliabilitas Data

\begin{tabular}{|l|c|c|}
\hline \multicolumn{1}{|c|}{ Variabel } & Alpha Cronbach & Keterangan \\
\hline Sarana (X1) & 0,699 & Reliabel \\
\hline Prasarana (X2) & 0,911 & Reliabel \\
\hline Mutu Pendidikan (Y) & 0,860 & Reliabel \\
\hline
\end{tabular}

Berdasarkan tabel hasil uji reliabilitas data diatas, dapat disimpulkan bahwa data penelitian dinyatakan reliabel, dimana nilai alpha untuk seluruh variabel penelitian lebih besar dari 0.60. dengan demikian butir pernyataan untuk variabel bebas dan variabel terikat dalam penelitian ini adalah reabel dan dapat dilakukan analisis lebih lanjut.

Berdasarkan analisis regresi linier berganda dengan memakai program SPSS for windows dapat disusun ringkasan hasil analisis regresi linier berganda sebagai berikut :

Tabel Rekapitulasi Analisis Regresi Linier Berganda

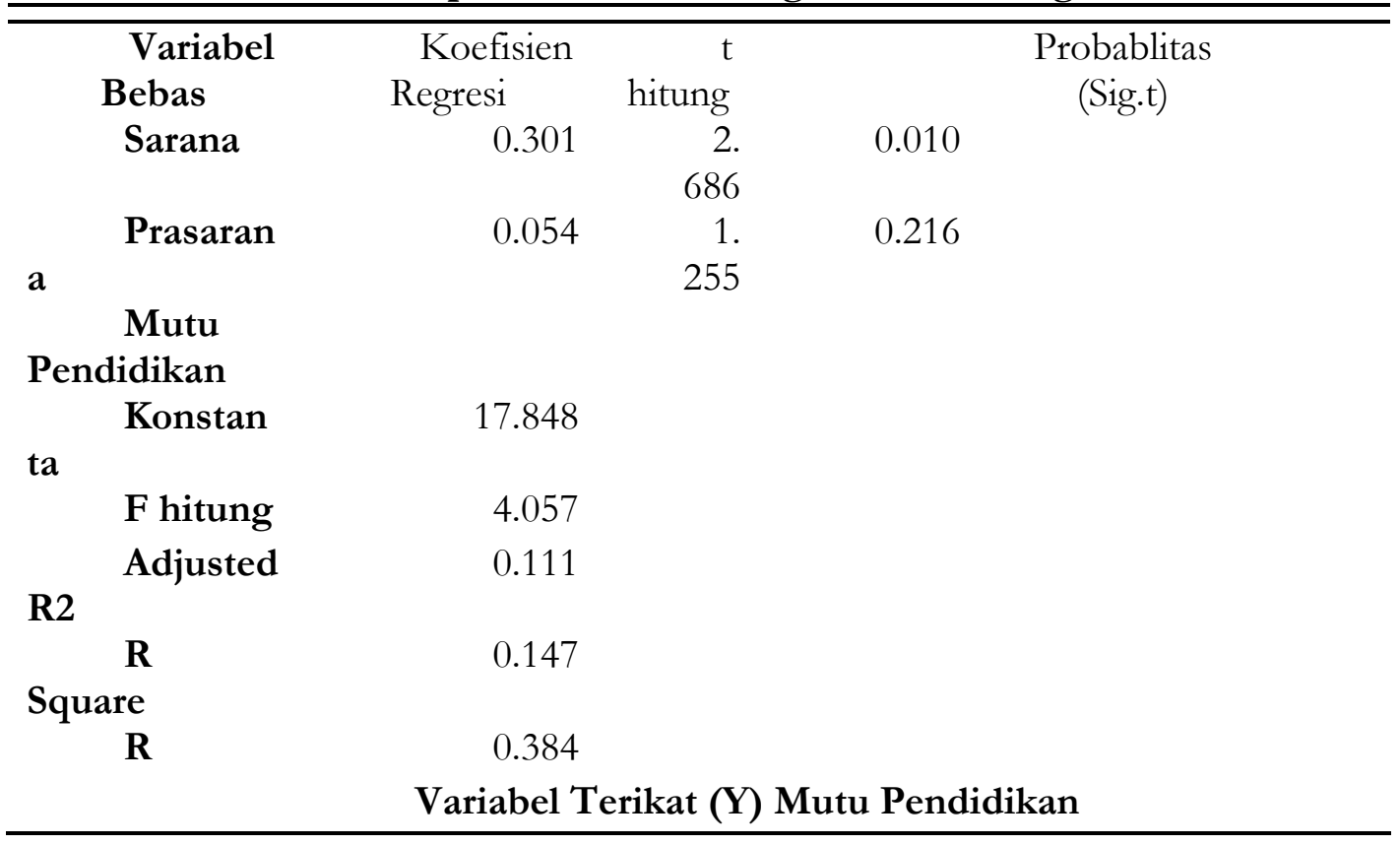

Berdasarkan tabel di atas bisa dibuat persamaan regresi linear berganda sebagai berikut yaitu $\mathrm{Y}=17.848+0,301 X_{1}+0,054 X_{2}$. Persamaan regresi tersebut bisa dijabarkan sebagai berikut yaitu konstanta $(\alpha)$ sebesar 17.848 menunjukan besarnya mutu pendidikan, jika tidak terdapat pengaruh dari variabel sarana $\left(X_{1}\right)$, prasarana $\left(X_{2}\right)$ atau dapat dikatakan jika variabel bebas adalah nol maka besarnya mutu pendidikan adalah sesuai nilai konstanta tersebut yaitu 17.848 . Koefisien regresi sarana $(\beta 1)$ memperlihatkan variabel sarana $\left(X_{1}\right)$ memiliki pengaruh sebesar 0,301 terhadap mutu pendidikan. Koefeisien regresi bernilai positif menunjukan pengaruh yang searah, artinya semakin tinggi nilai sarana yang diberikan akan menyebabkan semakin tinggi mutu pendidikan. Atau dapat dikatakan setiap penambahan 1 satuan variabel $\left(X_{1}\right)$ (sarana) akan ada cenderung untuk meningkatkan variabel terikat $Y$ sebesar 0.301 dengan asumsi variabel bebas lainnya adalah konstan. Koefisien regresi prasarana $(\beta 2)$ memperlihatkan variabel prasarana $\left(X_{2}\right)$ 
memiliki pengaruh sebesar 0.054 terhadap mutu pendidikan. Koefisien regresi berilai positif menunjukan pengaruh yang searah, artinya semakin tinggi nilai prasarana yang diberikan akan menyebabkan semakin tinggi mutu pendidikan. Atau dapat dikatakan setiap penambahan 1 satuan variabel $\left(X_{2}\right)$ (prasarana) akan ada kecenderungan untuk meningkatkan variabel terikat $\mathrm{Y}$ sebesar 0.054 dengan asumsi variabel bebas lainnya adalah konstan. Besarnya koefisien determinasi $\left(R^{2}\right)=$ 0,111 dan setelah disesuaikan menjadi adjusted $\mathrm{R}$ square sebesar 0.147 menunjukan bahwa sarana dan prasarana memberikan kontribusi sebesar $14.7 \%$ terhadap mutu pendidikan. Berdasarkan hasil perhitungan menggunakan persamaan regresi liner berganda diatas dapat terlihat kedua variabel bebas yang terdiri dari variabel sarana, dan prasarana yang dipakai di penelitian ini mempengaruhi variabel mutu pendidikan. Dimana dari kedua variabel tersebut yang mempunyai pengaruh dominan adalah variabel sarana.

Sarana (X1) mempunyai nilai yang lebih tinggi daripada variabel lain yakni 0.364, yang artinya sarana di MBI (Madrasah Bertaraf Internasional) Nurul Ummah dalam kualifikasi signifkan sedang. Hal ini menunjukkan bahwa sarana yang ada berhasil menunjukkan bukti kualifikasi signifikan sedang terhadap mutu pendidikan di MBI (Madrasah Bertaraf Internasional) Nurul Ummah. Berdasarkan hal ini maka sarana memiliki pengaruh terhadap mutu pendidikan.

Prasarana memiliki nilai kedua yaitu 0,170 dengan nilai ini berarti prasarana di MBI (Madrasah Bertaraf Internasional) Nurul Ummah dalam kualifikasi signifikan lemah. Hal ini memberikan bukti bahwa prasarana yang ada memiliki kualifikasi signifikan lemah terhadap mutu pendidikan. Berdasarkan hal ini terbukti bahwa yang namanya faktor prasarana adalah salah satu faktor yang tidak berpengaruh terhadap mutu pendidikan.

Mutu pendidikan di MBI (Madrasah Bertaraf Internasional) Nurul Ummah dalam hasil temuan ini bahwa mutu pendidikan yang ada memiliki hasil yang baik. Hal ini memberikan bukti bahwa mutu pendidikan yang baik bukan hanya berasal dari pengaruh variabel sarana dan prasarana saja melainkan ada varibel lain yang mempengaruhi.

Berdasarkan keseluruhan pembahasan tersebut bahwa dalam penelitian mutu pendidikan di MBI (Madrasah Bertaraf Internasional) Nurul Ummah dbisa dilaksanakan baik engan cara bertahap maupun keseluruhan, menggunakan penemuan yang ditemukan dari analisis regresi linier berganda, bahwa faktor sarana merupakan faktor yang lebih dominan daripada faktor prasarana

\section{KESIMPULAN}

Penelitian ini yaitu penelitian yang ditujukan untuk menjelaskan pengaruh variabel sarana dan prasarana terhadap mutu pendidikan di MBI (Madrasah Bertaraf Internasional) Nurul Ummah baik secara simultan (Uji F) maupun secara parsial (Uji t). Dengan teknik Regresi Linear berganda pada taraf signifikan 0.05 hasil penelitian menunjukan bahwa terdapat pengaruh yang signifikan antara sarana, prasarana terhadap mutu pendidikan. Dari dua (2) Variabel penelitian yang telah dilakukan analisis diketahui bahwa variabel sarana yang lebih dominan mempengaruhi mutu pendidikan daripada variabel prasarana.

Dengan memperhatikan hasil dari penelitian, dan kontribusi pemikiran bagi ilmu pengetahuan, khususnya dalam bidang mutu pendidikan dan MBI (Madrasah Bertaraf Internasional) Nurul Ummah, peneliti memberikan saran yaitu antara lain yaitu dari ketiga faktor yaitu sarana dan prasarana secara signifikan mempengaruhi mutu pendidikan di MBI (Madrasah Bertaraf Internasional) Nurul Ummah, maka disarankan untuk menjaga dan memlihara agar sarana dan prasarana yang ada tetap dalm kondisi yang memadai. Agar bisa dilaksanakan penelitian lagi dimasa yang akan datang dengan memakai variabel lain, hingga bisa didapatkan faktor atau variabel yang mempunyai kontribusi besar dan berpengaruh dominan terhadap mutu pendidikan MBI (Madrasah Bertaraf Internasional) Nurul Ummah. 


\section{REFERENSI}

A. Rusdiana. (2014). Konsep Inovasi Pembelajaran. Pustaka Setia.

Aan, K., \& Cepi, T. (2005). Visionary Leadership Menuju Sekolah Efektif. Jakarta: Bumi Aksara.

Abdullah, I., \& Safarina. (2015). Etika Pendidikan, Keluarga, Sekolah dan Masyarakat (Cet. 2). PT Raja Grafindo.

Abdurrahman, N. H. (2016). Character Education in Islamic Boarding School- Based Sma Amanah. Jurnal Pendidikan Islam, 2(2), 287-305. https://doi.org/10.15575/jpi.v2i2.791

Akhiruddin, K. M. (2015). Lembaga Pendidikan Islam di Nusantara. Jurnal Tarbiya, 1(1), 195-219.

Ari Fuazi, 211323796. (2018). Korelasi Standar Sarana dan Prasarana terbadap Prestasi Belajar Mahasiswa (Studi Komparatif Pesantren Sulaimaniyah dengan Pesantren Nurul Awal Aceh Besar) [Skripsi, UIN Ar-Raniry Banda Aceh]. http://library.ar-raniry.ac.id

Arifin, A. Z. (2017). Defending Traditions, Countering Intolerant Ideologies: Re-energizing the Role of Modin in Modern Java. Al-Jami'ab: Journal of Islamic Studies, 55(2), 265-292. https:// doi.org/10.14421/ajis.2017.552.265-292

Asrohah, H. (2011). The Dynamics of Pesantren: Responses Toward Modernity and Mechanism in Organizing Transformation. Journal of Indonesian Islam, 5(1), 66-90. https://doi.org/10.15642/JIIS.2011.5.1.66-90

Bashori, B. (2017). Modernisasi Lembaga Pendidikan Pesantren Perspektif Azyumardi Azra. Nadwa, 11(2), 269. https://doi.org/10.21580/nw.2017.11.2.1881

Burhan Bungin. (2006). Metode penelitian kualitatif.

Chairi, E. (2019). Pengembangan Metode Bandongan dalam Kajian Kitab Kuning di Pesantren Attarbiyah Guluk-Guluk dalam Perspektif Muhammad Abid al-Jabiri. Nidhomul Haq: Jurnal Manajemen Pendidikan Islam, 4(1), 70-89. https://doi.org/10.31538/ndh.v4i1.233

Chotimah, C. (2014). Pendidikan Kewirausahaan Di Pondok Pesantren Sidogiri Pasuruan. Inferensi: Jurnal Penelitian Sosial Keagamaan, 8(1), 114-136. https://doi.org/10.18326/infsl3.v8i1.114-136

Crosby, P. B. (1995). Quality Without Tears: The Art of Hassle-Free Management. McGraw Hill Professional.

Fajriana, A. W., \& Aliyah, M. A. (2019). Tantangan Guru dalam Meningkatan Mutu Pendidikan Agama Islam Di Era Melenial. Naz̧hruna: Jurnal Pendidikan Islam, 2(2), 246-265. https://doi.org/10.31538/nzh.v2i2.324

Farid, M., \& Daryanto. (2013). Konsep Dasar Manajemen Pendidikan di Sekolah. Gava Media.

Hamdi, A. (2019). Manajemen Mutu Program Diniyah Pada Pondok Pesantren MuhammadIyah Lamongan. Nidhomul Haq: Jurnal Manajemen Pendidikan Islam, 4(2), 247-258. https://doi.org/10.31538/ndh.v4i2.463

Hartono. (2011). Statistik untuk penelitian. Pustaka Pelajar.

Indonesien, \& Pusat Bahasa (Indonesia) (Eds.). (2013). Kamus besar bahasa Indonesia Pusat Bahasa: Edisi Keempat (Cetakan ketujuh Edisi 4). Gramedia Pustaka Utama.

Jerry H, M. (2011). Supervisi dan Peningkatan Mutu Pendidikan. Alfabeta.

Ma arif, M. A. (2017). Analisis Konsep Kompetensi Kepribadian Guru PAI menurut Az-Zarnuji. ISTAW A, 2(2), 35-60.

Maarif, M. A., \& Rofiq, M. H. (2018). Pola Pengembangan Kurikulum Pendidikan Pesantren Berkarakter: Studi Implementasi Pendidikan Berkarakter di Pondok Pesantren Nurul Ummah Mojokerto. 13, 16.

Masnur, M. (2007). Melaksanakan PTK (Penelitian Tindakan Kelas) itu Mudah. Bumi Aksara.

Mulyadi. (2010). Kepemimpinan kepala sekolah dalam mengembangkan budaya mutu Repository of Maulana Malik Ibrabim State Islamic University of Malang. UIN Maliki Press. http://repository.uinmalang.ac.id/1582/

Nasution, M. N. (2004). Manajemen Mutu Terpadu (Total Quality Management). Ghalia Indonesia.

Nata, A. (Ed.). (2003). Kapita selekta pendidikan Islam (Cet. 1). Angkasa.

Noor, J. (2011). Metodologi penelitian skripsi, tesis, disertasi dan karya ilmiah. Kencana Prenada Media Group. 
Pidarta, M. (2011). Manajemen pendidikan Indonesia. Rineka Cipta.

Sagala, S. (2016). Memahami Organisasi Pendidikan: Budaya dan Reinventing, Organisasi Pendidikan. Prenada Media.

Sagala, S. (2018). Pendekatan \& Model Kepemimpinan. Prenada Media.

Sekaran, U., \& Bougie, R. (2016). Research Methods For Business: A Skill Building Approach. John Wiley \& Sons.

Stoner, A. F., Freeman, R. E., \& Gilbert, D. R. (1996). Manajemen Edisi Bahasa Indonesia. PT. Prenhallindo. Jakarta.

Sugiyono. (1999). Metode penelitian bisnis. Alfabeta.

Sugiyono. (2014). Metode penelitian Kuantitatif Kualitatif dan R\&D (Ed. 14). Alfabeta.

Suharsimi, A. (2010). Prosedur Penelitian, Suatu Pendekatan Teori dan Praktek (14th ed.). Rineka Cipta.

Sulistyorini, M. F. \&. (2012). Implementasi manajemen peningkatan mutu pendidikan islam / Mubammad Fathurrohman. Teras.

Syafaruddin. (2002). Manajemen mutu terpadu dalam pendidikan: Konsep, strategi, dan aplikasi. Gramedia Widiasarana Indonesia.

Tunggal, A. W. (1992). Management audit: Suatu pengantar. Rineka Cipta.

Wafi, M. I. (2016). Pengaruh pemanfaatan sarana dan prasarana belajar terbadap prestasi belajar Pendidikan Agama Islam siswa kelas $X$ di SMAN 11 Semarang [Undergraduate, UIN Walisongo]. http://eprints.walisongo.ac.id/6126/ 